Litteratur

1. Reiakvam KK, Astor MC, Kittang BR. En kvinne i 70-årene med rask forverring av kognitiv funksjon. Tidsskr Nor Legeforen 2016; 136: 1096-8.

2. American Psychiatric Association. Diagnostic and Statistical Manual of Mental Disorders (DSM-5). https://www.psychiatry.org/psychiatrists/practice/dsm/ dsm-5 (20.7.2016).

3. Neerland BE, Watne LO, Wyller TB. Delirium hos eldre pasienter. Tidsskr Nor Legeforen 2013; 133: 1596-600.

4. Davis DH, Muniz Terrera G, Keage $\mathrm{H}$ et al. Delirium is a strong risk factor for dementia in the oldest-old: a population-based cohort study. Brain 2012; 135: 2809-16.

5. Pandharipande PP, Girard TD, Jackson JC et al; BRAIN-ICU Study Investigators. Long-term cognitive impairment after critical illness. N Engl J Med 2013; 369 : $1306-16$.

\section{K.K. Reiakvam \& B.R. Kittang svarer:}

Vi takker Wyller \& Watne for utfordrende kritiske kommentarer til vår artikkel (1), som gir oss anledning til å utdype viktige punkter i kasuistikken.

Vi er enige i det de skriver om viktigheten av delirium og utredningen av dette: raskt, grundig og på egnet nivå i helsetjenesten. Hovedinnvendingen mot oss er at vi ikke har gitt pasienten diagnosen delirium, og dermed vist manglende kunnskap om DSMs diagnosekriterier. Hvilken feil er det Wyller \& Watne mener vi har gjort? Vi har ikke glemt å tenke på diagnosen. Vi har vurdert og forkastet den, selv om vi ser at betegnelsen subsyndromalt delirium kanskje kunne vært anvendt (2). Vurderingen førte ikke til forsinket utredning eller feilbehandling. Ifølge Wyller \& Watne har vi feilklassifisert et klinisk bilde: Gjennom lesing av artikkelen og særlig vektlegging av uttrykkene «passiv», «likegyldig» og «fjern i blikket», finner de alle diagnostiske kriterier for delirium oppfylt. Men mens vi som klinikere har observert og vurdert en sykdomstilstand av en viss varighet, har de vurdert vår skriftlige gjengivelse av denne i kasuistikkform.

Mye kunne skrives om et krevende utvelgelsesarbeid under utformingen av artikkelen. La oss heller kortfattet prøve å gjengi litt mer av det kliniske forløpet: Da pasienten ankom sykehjemmet (dag 1) ble bevisstheten, som angitt i artikkelen, beskrevet som «klar», og frem til den akutte forverringen som førte til sykehusinnleggelse var hun klinisk stabil og uten tegn til endringer i bevisstheten eller fluktuerende symptomer. Da hun dagen etter innleggelse i sykehus ble skåret med Confusion Assessment Method kunne undersøkeren krysse «ja» på første spørsmål (akutt endring i mental tilstand), ellers «nei» på alle andre spørsmål (dvs. ikke vekslende forløp, uoppmerksomhet, desorganisert tankegang eller endret bevissthetsnivå). Ved gjentatte samtaler var hun rolig, samarbeidende, lyttende, og hun ga hele tiden blikkontakt, samtidig som blikket var påfallende «fjernt». Hun svarte på en måte som virket gjennomtenkt, men ordfattig, ikke typisk for fremre afasi. Hukommelsessvikten besto av en lettere anterograd amnesi, men atskillig mer uttalt retrograd amnesi, inkludert amnesi for personlige data. Beskrivelsen av pasienten som passiv og likegyldig kunne ha vært nyansert med hvordan hun paradoksalt nok samtidig fremsto som «åpen» og «tilbaketrukket». Hun var ikke psykomotorisk påvirket og viste ikke tegn til hyperaktivt eller hypoaktivt delirium. Tilstanden vedvarte, i jevnt avtakende grad under sykehusoppholdet.

Vi har aldri sett maken til dette sykdomsbildet, og flere andre sjeldne tilstander ble vurdert og utredet. Å beskrive slike atypiske kliniske forløp i den knappe form som en kasuistikk i Tidsskriftet krever, er utfordrende.

At artikkelen har skapt reaksjoner hos skarpe lesere, er forståelig. Men vi tror at dersom Wyller \& Watne hadde truffet denne pasienten mens hun var som sykest, så ville de opplevd hennes tilstand på en lignende måte - og muligens funnet mer treffende måter å beskrive den på.

Den aller største gleden ved arbeidet var for øvrig å bidra til at pasienten ble frisk, og uten sikre sekveler, vurdert ved våre kontakter med pasienten i ettertid.

Kyrre Kittang Reiakvam

kyrre.kittang.reiakvam@haraldsplass.no

Bård Reiakvam Kittang
Kyrre Kittang Reiakvam (f. 1975) er overlege og spesialist i indremedisin og i geriatri ved Medisinsk avdeling, Haraldsplass Diakonale Sykehus. Ingen oppgitte interessekonflikter.

Bård Reiakvam Kittang (f. 1971) er overlege, ph.d. og spesialist i indremedisin og i infeksjonssykdommer ved Avdeling for sykehjemsmedisin og Medisinsk avdeling. Haraldsplass Diakonale Sykehus.

Ingen oppgitte interessekonflikter.

\section{Litteratur}

1. Reiakvam KK, Astor MC, Kittang BR. En kvinne i 70-årene med rask forverring av kognitiv funksjon. Tidsskr Nor Legeforen 2016; 136: 1096-8.

2. Meagher D, Adamis D, Trzepacz $P$ et al. Features of subsyndromal and persistent delirium. Br J Psychiatry 2012; 200: 37-44

\section{Re: Incentiver og deltagelse i en medisinsk spørreundersøkelse}

Jeg har med interesse lest Gjøstein og medarbeideres studie (1), der de finner at å vedlegge et skrapelodd ikke øker svarprosenten ved utsendelse av spørreskjema. Jeg er imidlertid overrasket over at forfatterne i diskusjonen ikke nevner det økonomiske incentiv som er vist å virke best: cash! Forfatterne refererer til et av våre arbeider (2) der vi fant at skrapelodd ikke hadde virkning. Vi tenkte i ettertid at forklaringen kanskje kan være at mottageren i utgangspunktet blir glad for skrapeloddet, men så straks skraper det. Han vil vanligvis ikke få gevinst, og det er mulig at denne skuffelsen heller virker demotiverende enn motiverende for å fylle ut og returnere skjemaet. Forfatterne nevner ikke at vi i det samme arbeidet fant at svarprosenten økte fra 73 hos dem som hadde fătt et skrapelodd til 88 ved i stedet å legge ved en 50-kroneseddel. En Cochrane-gjennomgang (3) konkluderte at et pengebeløp er det beste av alle rapporterte incentiver. I Norge må imidlertid det vedlagte beløpet være ganske stort for å ha virkning. Vi fant i en annen studie (4) svarprosenter på 54 uten penger, 53 med én krone, 58 med ti kroner, og 74 med 50 kroner. Det kan med andre ord bli nokså kostbart, men er muligens regningssvarende om alternativet er å betale et firma for å ringe til dem som ikke har svart, slik det ble gjort i Gjøstein og medarbeideres studie. Gevinsten er en god svarprosent og derved bedre forskning.

\section{Vilhjalmur Finsen}

vilh.finsen@ntnu.no

Vilhjalmur Finsen (f. 1946) er overlege og professor ved St. Olavs hospital og Det medisinske fakultet, Norges teknisk-naturvitenskapelige universitet.

Ingen oppgitte interessekonflikter.

\section{Litteratur}

1. Gjøstein DK, Huitfeldt A, Løberg M et al. Incentiver og deltagelse i en medisinsk spørreundersøkelse. Tidsskr Nor Legeforen 2016; 136: 1082-7.

2. Finsen V, Storeheier AH. Scratch lottery tickets are a poor incentive to respond to mailed questionnaires. BMC Med Res Methodol 2006; 6: 19

3. Edwards PJ, Roberts I, Clarke MJ et al. Methods to increase response to postal and electronic questionnaires. Cochrane Database Syst Rev 2009; 3: MR000008. 4. Finsen V. Tiltag for at $\varnothing g$ ge svarprocenten ved spørgeskemaunders $\varnothing$ gelser Ugeskr Laeger 2011; 173: 39-41.

\section{D.K. Gjøstein og medarbeidere svarer:}

Finsen fremhever flere viktige poeng rundt det praktiske og kostnadsmessige ved valg av tiltak for å øke svarprosent i medisinske spørreskjemaundersøkelser. Det er uklart om skrapelodd øker svarprosenten $(1,2)$, og i vår studie fant vi ingen effekt (3). Finsen har tidligere funnet at ubetingede incentiver $\mathrm{i}$ form av kontanter synes å ha høyere effekt enn skrapelodd, men dette forutsetter at kontantbeløpets størrelse er betydelig (4). 
Den primære hensikten med spørreskjemaet var å få respons fra et representativt utvalg av de som ikke møtte til screening, og fra personer randomisert til kontrollgruppen til bruk i senere analyser av NordICC-studien. Dersom samtlige deltagere i vår studie skulle gis et kontantbeløp av tilsvarende størrelse som det effektive beløpet i Finsens studier (50 kroner), ville kostnaden bli høyere enn en strategi om å ringe dem som ikke hadde svart. Hvorvidt den ene eller andre strategien gir det mest representative utvalget er vanskelig å si. Dersom økning i svarprosent samsvarer med økning i representativitet, synes de to metodene omtrent jevngode.

\section{Dagrun Kyte Gjøstein}

d.k.gjostein@medisin.uio.no

Michael Bretthauer

Magnus Løberg

Dagrun Kyte Gjøstein (f. 1986) er sosialantropolog og doktorgradsstipendiat ved klinisk effekt-forskningsgruppen ved Universitetet i Oslo/Oslo universitetssykehus.

Ingen oppgitte interessekonflikter.

Michael Bretthauer (f. 1969) er professor ved Universitetet i Oslo og overlege ved Gastromedisinsk seksjon, Avdeling for transplantasjonsmedisin, Oslo universitetssykehus.

Ingen oppgitte interessekonflikter.

Magnus Løberg (f. 1979) er lege og postdoktor ved klinisk effekt-forskningsgruppen ved Universitetet i Oslo/Oslo universitetssykehus. Ingen oppgitte interessekonflikter.

\section{Litteratur}

1. Finsen $\mathrm{V}$, Storeheier $\mathrm{AH}$. Scratch lottery tickets are a poor incentive to respond to mailed questionnaires. BMC Med Res Methodol 2006; 6: 19

2. Olsen F, Abelsen B, Olsen JA. Improving response rate and quality of survey data with a scratch lottery ticket incentive. BMC Med Res Methodol 2012: 12: 52

3. Gjøstein DK, Huitfeldt A, Løberg $M$ et al. Incentiver og deltagelse i en medisinsk spørreundersøkelse. Tidsskr Nor Legeforen 2016; 136: 1082-7.

4. Finsen V. Tiltag for at $\varnothing g e$ svarprocenten ved spørgeskemaunders $\varnothing g e l s e r$ Ugeskr Laeger 2011; 173: 39-41.

\section{Re: Ikke langvarig antibiotikabehandling ved sykdom tilskrevet borreliose}

Det redaksjonelle innlegget ved Martine Rostadmo i Tidsskriftet nr. 11/2016 (1) berettiger en kommentar. Publikasjon fra Nederland (2) tillegges større vekt enn den fortjener. Presentasjonen er pen, men problemet er at inklusjonen av pasientene er diffus. Pasientene er til dels inkludert med diffuse plager og et IgG- eller IgM-funn. Kvantitering av IgG er ikke nevnt. IgM-immunoblot er bedømt etter fabrikantens kriterier. Her er det stor usikkerhet om et solitært IgMbånd for OspC som fabrikanten angir, kvalifiserer til positiv prøve eller ikke.

Samme forskergruppe har tidligere redegjort for sitt prosjekt (3). Inklusjonskriteriene er her tydeligere presisert enn i artikkelen i New England Journal of Medicine. Uklarheten består likevel. Man merker seg at vel $20 \%$ av pasientene ikke har noen form for positiv serologi. Når pasienter med artralgi eller andre muskel-skjelettsymptomer utgjør over $90 \%$, er det en merkelig diskrepans. Dette forsterkes av en upresist angivelse av serologisk støtte.

Jeg tror ikke denne artikkelen kan brukes til noe som helst i den infeksjonsmedisinske hverdag. Hvilken prosess som ligger bak publisering i New England of Medicine, er for meg gåtefullt.

\section{Per H. Bjark}

bjap@ous-hf.no

Per H. Bjark (f. 1938) er pensjonert overlege og spesialist i infeksjonssykdommer.

Ingen oppgitte interessekonflikter

\section{Litteratur}

1. Rostadmo M. Ikke langvarig antibiotikabehandling ved sykdom tilskrevet borreliose. Tidsskr Nor Legeforen 2016; 136: 989

2. Berende A, ter Hofstede HJM, Vos FJ et al. Randomized trial of longer-term therapy for symptoms attributed to Lyme disease. N Engl J Med 2016; 374 1209-20.

3. Berende A, ter Hofstede HJ, Donders AR et al. Persistent Lyme Empiric Antibiotic Study Europe (PLEASE)-design of a randomized controlled trial of prolonged antibiotic treatment in patients with persistent symptoms attributed to Lyme borreliosis. BMC Infect Dis 2014; 14: 543.

\section{Re: Ikke langvarig antibiotikabehandling ved sykdom tilskrevet borreliose}

Hvordan en best kan håndtere personer som har persisterende symptomer attribuert til borreliose, er et viktig og uavklart problemområde. Det er riktig som kommentert at det ikke var noe inklusjonskrav at man fant aktiv borreliainfeksjon eller positive borreliaantistoffer i studien. Kriteriet var at de inkluderte, eller henvisende lege, var sikre på at personen hadde en aktiv borreliainfeksjon som årsak til sine kroniske plager. Majoriteten av pasienten hadde ukarakteristiske plager som muskelsmerter, slitenhet og subjektive kognitive plager. Denne kliniske problemstillingen vil de fleste leger kjenne igjen fra egen praksis som relativ hyppig og utfordrende $(1,2)$. Det diskuteres fremdeles i mange miljøer om disse plagene kan skyldes en kronisk infeksjon som man ikke finner med vanlige diagnostiske metoder, og som bør behandles med langvarig og repeterte antibiotika. Enkelte private klinikker og leger i Norge og andre land har diagnostisert og behandlet/behandler nettopp denne pasientgruppen med langvarige og kombinerte antibiotikakurer, uten tilstrekkelig vitenskapelig grunnlag eller sikker diagnose. Det er denne pasientgruppen de nederlandske forskerne har inkludert. Resultatet er altså at det ikke er noen tilleggseffekt av lengre behandling. Derfor er denne publiseringen viktig.

\section{Randi Eikeland}

Randi.Eikeland@sshf.no

Randi Eikeland er nevrolog og leder for Nasjonal kompetansetjeneste for flåttbårne sykdommer.

Ingen oppgitte interessekonflikter.

\section{Litteratur \\ 1. Ljøstad U, Mygland $\AA$. The phenomenon of 'chronic Lyme'; an observational study. Eur J Neurol 2012; 19: 1128-35 \\ 2. Eikeland R, Mygland A, Herlofson K et al. European neuroborreliosis: quality of life 30 months after treatment. Acta Neurol Scand 2011; 124: 349-54.}

\section{Re: Hjelp bøndene i kampen mot MRSA}

Peer Ola Hofmo setter søkelyset på et viktig tiltak for å hindre smitte med meticillinresistente Staphylococcus aureus (MRSA) i Norge (1). Helsemyndighetene anbefaler MRSA-testing for blant annet utenlandske arbeidstakere før de starter å arbeide i norske svinebesetninger (2). Hofmo refererer at mange blir avvist når de kommer til MRSA-testing. Det er grunn til å minne om at bærerskap med MRSA er definert som en allmenfarlig smittsom sykdom, og dermed gjelder rettigheter og plikter i smittevernloven (3). Helse- og omsorgsdepartementet har redegjort nærmere for dette i rundskriv til alle landets kommuner 11.3.2015 (4). Der heter det blant annet: «Smittevernloven fastsetter ikke en plikt for alle fastleger til å kunne teste for MRSA, men de må eventuelt henvise pasienten til en annen lege i kommunen som kan gjøre dette.»

Leger må altså ikke bare oppfordres til å teste svinearbeidere for MRSA. Etter smittevernloven har de en plikt til å sørge for at de blir testet, enten legen gjør det selv, eller henviser til et annet tilbud i kommunen. 